\title{
Writing in the Blank Space of Manuscripts: Evidence from the Ninth Century
}

Mariken Teeuwen

Huygens Institute, The Hague, The Netherlands

In medieval manuscripts the main text is only one aspect of what these books reveal to us about the past. The vast majority of manuscripts that survive also contain annotations and additions, which reflect how these manuscripts were read, used, extended, summarized or criticized by their circles of copyists and readers. In the project 'Marginal Scholarship: the Practice of Learning in the Early Middle Ages (c. 800-c. I000)', it is our aim to map these textual practices, in order to gain a better understanding of the intellectual world they reflect. ${ }^{.}$We make an inventory of phenomena we encounter in the margin, such as marginal keywords or indices, organizing or structuring strategies, commentaries and signs. Scribal activity in the margin is characterized by its own set of specific characteristics and practices. It displays, for example, the tendency to be built up in layers and to accumulate over time. It has, furthermore, a typical commonness of various sets of signs, such as Tironian notes, signs for textual criticism and reader guidance, or signs linking annotations to words or phrases in the main text. These practices may be individual or shared; they may be either characteristic for certain individuals, or for certain scribal communities or even certain periods. Their developments, consequently, illustrate not only how schools or communities developed their own 'scribal identity', but also how practices were shared between monasteries or scholars through travel and intellectual contact. Thus an analysis of these features may give us valuable tools for comparison, distinction, dating and localization, just as the palaeographical and codicological analyses of manuscripts do. The mapping of such features is one of the goals of the project as a whole.

This lecture was given on 22 October 2012 at Stockholm University.

How to cite this book chapter:

Teeuwen, M. 20I6. Writing in the Blank Space of Manuscripts: Evidence from the Ninth Century. In: Crostini, B., Iversen, G. and Jensen, B. M. (eds.) Ars Edendi Lecture Series, vol. IV. Pp. I-25. Stockholm: Stockholm University Press. DOI: http://dx.doi. org/IO.I6993/baj.b. License: CC-BY 4.0 
Let me state this, however, in advance: the main focus of our project is not on the edition of marginal texts. This subject is problematic and, in my view, has greatly suffered under the traditional philological approach, where the text in the centre of the page was generally cast as the protagonist, and marginal text ignored. In the traditional philological approach, furthermore, it is generally assumed that the text has a stable, optimal form which can be reconstructed by the comparison of variants. Marginal texts are among those, which do not always adhere to this dogma; in many cases they are fundamentally different in nature. ${ }^{2}$ Thus, even if we do not intend to make scholarly editions of marginal texts part of our project, it seems important to discuss the matter with an audience of textual scholars, in order to establish how marginal texts should be treated by editors (and cataloguers) in such a way that they give access to the information they contain in the best possible way.

Before I start with observations on the phenomenon of writing in the margin in the Carolingian period, I would like to make clear that the phenomenon was not new in this period. On the contrary: in all ages and regions and from our earliest written witnesses on, we can see that the space around a text attracted new text. 'Marginalia' are inscribed on the sides of Babylonian clay tablets, and we have annotations on first century papyri. ${ }^{3}$ If we zoom in on the history of writing practices in the western European world and leaf through the invaluable Codices Latini Antiquiores, close to sixty manuscripts which are described in Lowe's volumes are observed to contain some form of annotation. Moreover, in about two-thirds of these cases, the annotations are contemporary or near contemporary. ${ }^{4}$

Already in the late-antique material, these annotating practices can be observed to come in many different shapes and sizes. Often they took the form of occasional reflections on the text, such as the insertion of corrections, variant readings or the presence of lacunae. A large scale annotation with scholiae or settled commentary traditions is also found, already in Late Antiquity, and so is the insertion of extra, not necessarily related texts into marginal space. ${ }^{5}$ Commentary traditions, however, could also be transmitted in separate, free-standing manuscripts, where the connection to the main text to which the commentary is linked is only present in the form of lemmata. ${ }^{6}$

Carolingian scribes thus encountered the practice of annotating a text in the margin in the codices they inherited from Late Antiquity. They were not inventing a new technique when they filled the margins 
and interlinear spaces of their own manuscripts. Still, it is obvious that the practice of writing in the margin underwent a significant change in the Carolingian period. 7 The new approach of Carolingian culture to manuscripts, teaching and learning boosted a practice which amplified the practice of writing in the blank space of manuscripts, and which would lead up to the complex biblical glossa ordinaria lay-outs that we know from the twelfth and thirteenth centuries. ${ }^{8}$ The features of Caroline minuscule, and the Carolingian concern with developing a new book layout suited a practice of writing text in the margin: in this period, books were created with wide margins, extra columns, relatively wide spacing in between the lines. ${ }^{9}$ These changes in layout and script support the hypothesis that textual practices changed, and that writing annotations around a text gained in frequency and importance in the period.

A numerical comparison of the manuscript evidence from the Carolingian period and the period before is also telling, although we have to take into account a degree of uncertainty here because of the scarcity of material that survived from before the ninth century. Nevertheless, a rough guess of the percentage of manuscripts with annotations in the margins in the period before the ninth century, counting from papyri collections and the descriptions in Codices Latini Antiquiores, would give us a figure of less than I०\%. From the ninth century onwards, on the other hand, we would guess that figure is closer to $80 \%$ or $90 \%$. It is hard to be precise here, because a systematic evaluation of scribal activity in all Carolingian manuscripts has not been conducted, and is perhaps unfeasible considering their high number. But an inventory of manuscripts from the Bavarian region (digitized by the Bayerische Staatsbibliothek) gave us this percentage, even when the Bavarian region is not particularly known for its high-end intellectual culture in the period. ${ }^{\text {Io }}$

Indeed, this observation is confirmed by a more general survey of marginal activity in early medieval manuscripts. In a database in which we are collecting our observations on marginal activity, annotated manuscripts are the rule, and manuscripts with blank margins and empty interlinear spaces are the exception. They are found in the category of Prachthandschriften, manuscripts that are beautifully written, richly decorated, prepared to be given to a king, such as, for example, the Vivien Bible, made in Tours in the middle of the ninth century for Charles the Bald. ${ }^{\text {II }}$ This makes sense: no scribe would write in the margins of such a beautiful and costly book. Perhaps there are more categories to be found of 'empty books', that is, books with empty margins. 
The extent of annotation in non-empty books varies widely, of course. The scale goes from just a few words in the margin — sometimes not even words but simply some signs or numbers-, to a fully filled space around the main text. In order to understand and be able to describe the practices of annotating in the early middle ages, questions of quantity were among the first we asked ourselves: How many annotations make a manuscript 'densely annotated'? Are different categories of texts to be accompanied by different expectation patterns? The proverbial schoolbook, for example, is certainly more prone to acquire layers of dense annotation over time than a liturgical book, or even the work of a Church Father. In order to measure the amount of annotation, we devised a three-fold method. Given the time-span of the project and the complexity of the mise-en-page of commentary texts, it is just not feasible to count single annotations on pages. Instead, we chose to count the number of pages that have annotations out of the first 40 pages. Second, we count the total number of 'blank' pages (that is 'with pristine margins and interlinear spaces') in a manuscript, and third, we measure the percentage of the margin filled with writing on the most densely annotated page. Next to these data with measurements, we also store information about the kind of text that is in a manuscript (poetry, liturgy, liberal arts, etcetera), so that we are able to establish the relation between textual genres and density of annotation. Thus, we will be able to filter out the norm and the exception: a schoolbook with only a $5 \%$ filled margin on the most densely annotated page will pop up as an exceptionally empty book, whereas a copy of Augustine's De civitate dei with the same percentage in the same observation field will be closer to the norm.

Next to these data on the quantity of annotations, we store information about dates, places of origin, places of provenance and persons and locations involved in the history of a manuscript. We hope to be able to detect patterns here as well: who were the agents involved in writing marginal annotations, and where is the evidence for certain annotating practices stronger than elsewhere? Which specific writing practices could be linked to specific writing centres, to certain scholars or their circles, or to a certain period? Once our database will be filled with a wide-enough sample of data, we will be able to see the answers to these and similar questions. ${ }^{\mathrm{I} 2}$ For the moment, however, my observations on the nature of marginal scholarship will be more haphazard and intuitive, based on examples gathered from my earlier research on Martianus Capella commentary traditions and enriched by leafing through manuscripts, digital facsimiles, articles and editions. 


\section{Purpose and function of annotated books}

In his article Talking Back to the Text Christopher Baswell wrote: 'medieval edges (especially codicological) are the places that make space for new and characteristic ideas, communities, and voices in the period'. ${ }^{13} \mathrm{He}$ argues that the practice of annotating manuscripts with commentary and authoritative explanations, which were meant for the classroom, had the perhaps unwanted side-effect of creating a space for differences of opinion, for doubting the authorities and for rebellion. He illustrates this with late medieval examples in Latin and Middle English, but according to me he raises a crucial point for our approach to marginal text, which previous scholarship has failed to uncover. Yes, the margin was a space in which the authorities were given their authorial weight, by explaining them and elaborating upon their arguments. But it was also a space where multiple authorities were gathered, where their contradictions, weaknesses and errors were openly displayed, and where discussion took place. Moreover, when we assess the annotated book solely as a book meant for the classroom, we do not do full justice to the manuscript material that we have, and we do not see the whole picture of how medieval scribes, scholars and readers dealt with their texts. Outside the narrow view of the schoolbook, annotating practices also took place, for example in the shape of personal markings which redacted, summarized and reorganized texts in order to make them ready for a transport to new contexts. And even within the traditional schoolbook context, a new approach which includes these other kinds of annotating practices makes the margin much more interesting than the traditional view, in which the schoolteacher's glosses are to be categorized into prosodical glosses, lexical glosses, morphological glosses, syntactical glosses, etcetera. ${ }^{\mathrm{I} 4}$ Of course, patiently educating voices of grammar teachers are also present in the margin, and to analyse how text is explained in the classroom is valuable research, but there is more to discover. The following examples support this claim.

\section{Collecting authorities and related material}

In Martianus Capella's De nuptiis the seven liberal arts are treated in a nutshell, embedded in the story of how Mercury seeks a suitable bride, and finds her in the earthly maiden Philology. With the consent of the gods, it is decided that Philology will be allowed to make a journey into heaven, being deified in the process, and that the newly-weds will receive the gift of the Seven Liberal Arts at the wedding banquet. ${ }^{\text {I5 }}$ 
Martianus is an embellisher: he likes to dress up his dreary knowledge with rich clothes, to give them mysterious epithets and to use wit and even a bit of sex in the frame story. The Carolingian scholars engaging with the text loved him for it. They ate his book like heavily honeyed porridge, spilling none of it. That at least is the impression one gets when looking at the margins of Martianus manuscripts, which tend to be filled to the brim with annotations. Let me give you an illustration of Martianus's literary world with a passage from the first book:

[I74] There came also a girl of beauty and extreme modesty, the guardian and protectress of the Cyllenian's home, by name Themis or Astraea or Erigone; she carried in her hand stalks of grain and an ebony tablet engraved with this image: [175] In the middle of it was that bird of Egypt which the Egyptians call an ibis. [176] It was wearing a broad-brimmed hat, and it had a most beautiful head and mouth, which was being caressed by a pair of serpents entwined; under them was a gleaming staff, goldheaded, gray in the middle and black at the foot; under the ibis' right foot was a tortoise and a threatening scorpion, and on its left a goat. [I77] The goat was driving a rooster into a contest to find out which of the birds of divination was the gentler. [ $\mathrm{I} 78$ ] The ibis wore on its front the name of a Memphitic month. ${ }^{16}$

The passage is an apt illustration of the abstruse, mystifying world of Martianus. ${ }^{17}$ Erigone comes in carrying an ivory image: on it, an ibis is depicted, wearing a 'sombrero' style hat, the name of a Memphitic month on its chest; snakes curling around its beak; it stands on a tortoise, a scorpion and a goat kicking a rooster into action - the meaning of all this must have been completely beyond any reader who did not have the same cultural and educational background as Martianus Capella himself. Why, then, did Carolingian scholars read this, and how did they interpret its bewildering imagery? The passage, as found in one of the oldest and fullest annotated manuscripts that has survived, Leiden, UB, VLF 48 , fol. $\mathrm{I} 7 \mathrm{r}$, is transcribed in the digital edition which I created in collaboration with Sinead O'Sullivan, Mary Garrison, Natalia Lozovsky, Jean-Yves Guillaumin and Bruce Eastwood. It is attached to this paper in an appendix. ${ }^{18}$

As we can see there, our Carolingian readers and interpreters certainly did not give up easily: no less than 27 annotations are attached to this passage, interacting with the text at different levels: explaining, paraphrasing, widening the scope of the reader's understanding by presenting him/her material from different sources on the same subject: material that is found 
in Isidore's Etymologies, in Hyginus' Fabulae, in Bede's De temporum ratione, and in the late antique glossary tradition. ${ }^{19}$ By assembling a collection of references to other materials, the annotations create a context for Martianus' fleeting allusions to a world that was no longer part of the background of the average reader.

This method is definitely not peculiar to annotations on Martianus Capella. I have argued elsewhere that the oldest layers of commentary added to Boethius' De institutione musica reflect the same approach to the text as those added to Martianus. ${ }^{20}$ The two traditions frequently refer to each other's central texts (especially on the subjects of arithmetic and music, because Boethius wrote two handbooks on these arts); they compare the claims of Boethius with those of Martianus and vice versa. In other words: the voices in the margins of Martianus's text connect his learning with that of Boethius, and the other way around.

The nature of Carolingian glosses added to Priscian was analyzed by Franck Cinato, and he found the same principles of creating in the margin a network of authorities in his sources. ${ }^{21}$ And in the Carolingian commentary traditions on Virgil, currently under research by Silvia Ottaviano and Sinead O'Sullivan, exactly the same kind of processes are observed. ${ }^{22}$ The margin is a place suited for a collection of related material - a place where one can bring together all the material one has on a certain subject, be it some piece of geographical learning which can be found in Pliny, or a piece of mythological learning which could be gained from Servius' commentary to Virgil, or a piece of technical learning on the liberal arts, to be gained from Martianus or Boethius.

\section{Sorting, selecting and criticizing}

Apart from collecting extra material, organizing material is one of the most common phenomena used in the margins: very often, annotations organize the text for the reader, to make it easier to follow, to find, to remember. Examples of such organizing strategies are marginal indexing - the repeat of a key term in a passage in the margin, often in capitals-; numbers in the margin; the indication of names in the margin in a text which is a collection of material from others. The purpose of these marginalia is to help or facilitate the process of knowledge management. ${ }^{23}$ The scholarly content of the book was stored, sorted, selected, and summarized with the help of a set of shared practices, involving the visualisation of textual structure with a shared set of signs 
and marks: nota signs, numbers, s or ss for quotes, capital letters for indexing glosses, critical signs such as asterisk and obelus.

The latter category of signs is an intriguing element of the writing practices of the time. Evina Steinová is at present preparing a study on the practice of using these signs to mark passages in the margin: dots, lines, crosses, circles, diple, obelus, asteriscus, chrisimon, achriston, fietro, theta, etcetera. ${ }^{24}$ Their history can be traced back to Antiquity: in the time of the great library of Alexandria, they were used for textual criticism, to mark variants and suspicious textual passages. In the books of the Church fathers they are deployed not only for textual critique, but also for content critique, to mark passages where dogmatic differences may be detected. This already happened before the Carolingian period, and Carolingian writers in turn adopted signs, created new ones and used them according to their own new systems of meaning. When we study the late antique and medieval testimonies that reflect upon the theory of using the signs and about their meaning, it becomes clear that there is no uniformity here, but rather a range of different traditions. The practice of using the signs in medieval manuscripts, moreover, shows a similar widely varying plethora of shapes and meanings.

For example, the Greek theta is used in Antiquity to mark the fallen in the list of soldiers who entered in a battle, or in law the names of those sentenced to death, theta being short for 'thanatos', death, as is described in Isidore's Etymologies I.3.8, in the section on De litteris communibus. But an anonymous Irishman working in Milan in the second half of the ninth century (once thought to be Sedulius Scottus) uses the theta to give structure to his translation work: he compares the Greek, Hebrew and Latin versions of the Psalter, and flags in his translation passages which are superfluous in the Latin version with a theta. Here the theta means: this passage is only present in the Latin version, and it is neither present in the Greek version nor in the Hebrew one. ${ }^{25}$ Prudentius of Troyes uses it in yet a different manner: he marks the words of John the Scot with a theta in his treatise against John in the Predestination debate. With the use of the theta, he flags his unease and disagreement with John the Scot's words, against whose opinions he strongly argued in this particular, heated debate. ${ }^{26}$ Thus Prudentius seems to blend practices here and give them a new layer of meaning: not only does he organize the main text, indicating to the reader where the words of John are used in the text, but he also voices his criticism, by indicating with the theta signs that these words are to be mistrusted, to be dismissed, or even: declared dead. 


\section{Open criticism}

The use of signs may perhaps be interpreted as a silent way of voicing critique: passages to be treated with suspicion were flagged, but not removed or openly doubted or attacked. One could argue that these practices were meant just for insiders or the scholar in question himself and his close circle. We also have, however, more eloquent examples of 'talking back to the text'. The most famous of these is perhaps the attack on Amalarius of Metz by Florus of Lyon or people from his circle as apparent in Paris, BnF, NAL $329 .{ }^{27}$ Florus was deacon in Lyon in a troubled time, when Amalarius was appointed there by Louis the Pious as interim archbishop - to the chagrin of the monastic community, for he replaced Agobard, who was much preferred by them. Florus was also the person in charge of the scriptorium of Lyon, where he ruled the activities of his scribes in a most meticulous fashion. ${ }^{28}$ In a manuscript of Amalarius' treatise on the liturgy, the Liber officialis, copied in Lyon at the time of Florus, the margins are filled with denigrating remarks about the main text: 'rara insania', 'exiguissimi sensus verba', 'mira vanitas', 'rabida locutio', 'stultissimum mendacium' and 'insanissima falsitas'. On several instances, the annotations directly address Amalarius in second person. The sarcastic tone is abundantly clear from an annotation responding to Amalarius' explanation of the symbolic meaning of a shaved head (namely to get rid of superfluous thoughts from the upper part of the mind): ${ }^{29}$

Si capilli superflui superfluas cogitationes significant et ideo tonderi aut radi debent, multum tibi necesse erat ut non solum caput corporis sed etiam mentem raderes unde tanta superflua prodeunt. ${ }^{3 \circ}$

If superfluous hairs signify superfluous thoughts and therefore are to be tonsured or shaved, then it is very necessary for you that you should not only shave the head of your body, but also your brain, since so many superfluous things come from it.

The 'talking back to the text' can thus take various shapes: from bringing structure to widening the scope of a text, embedding it into a context, to the addition of other authorities, differing authorities, criticism, or even biting off each other's heads. Baswell remarks that the margin was seen as a 'safe arena', a space where 'ignored or suppressed voices or preoccupations (and the textual communities implicit behind them) ... are able to enter into conflict with it'. ${ }^{3}{ }^{3}$ One of his examples is William of Conches, who allowed himself to speculate on the Platonic World-Soul 
as the Holy Spirit, even though this sets off alarm bells ringing in his head, screaming 'heresy'.32 Within the Marginal Scholarship project we are finding our own examples of these processes in the ninth century: for example, predestination being explored even after the synod that explicitly stated that this subject should be put to rest, at least for the time being. ${ }^{33}$

In this case, moreover, an 'empty' book may be a telling example of annotating practices and their importance in the ninth century: Paris, Bibliothèque de l'Arsenal, ms. 663, a copy of the Libri Carolini, made in Rheims in 869 or 870 and containing Theodulf of Orléans' contribution to the debate about the use of images in church. It is remarkable that this book has empty margins except for a few numbers marking sections. The debate was one of the larger debates in the Carolingian empire, in which king Charles the Bald involved the greatest minds of his intellectual circle. In the Libri Carolini statements must have been included to which others would have wanted to raise objections. We could speculate that the blank margins are, in this case, a statement rather than a coincidence. Perhaps these empty margins display the king's wish to end the debate with this book, even when no consensus had been reached. ${ }^{34}$

\section{Quotations and associative connections to different authorities}

So, the interaction with the text and the 'vocal' quality of it, as described by Baswell, is a phenomenon that an editor should be sensitive to, and try to take into account when preparing an edition of marginal text. The other major aspect that makes marginal texts hard to deal with from an editorial point of view, is their intertextuality: in the margins we can see how scholars were cutting up their texts into digestible pieces, 'nuggets of knowledge' so to speak, that could be comprehended and stored in the memory. For example: the margins of De nuptiis are full of repeats of definitions, or pointers to places where definitions occur in Martianus' text. These definitions ended up in other places: for example, the definition of 'tonus' a tone, namely a 'spatium cum legitima quantitate', a space with a legitimate quantity, is found in De nuptiis, quoted in the oldest commentary traditions to Boethius De institutione musica, and found again in the later ninth- and tenth-century music treatises by writers such as Aurelian, Regino of Prüm, or Hucbald. ${ }^{35}$ The chopping up of the text into easy to store chunks and moving those around to other places happens on a wide scale. The margins could 
be likened to a magpie's stash, containing shining items of hard-won learning from other authorities. ${ }^{36}$

The phenomenon of explicit referral to other authorities or texts is frequent, but implicit quotation is even more frequent. For example, a long annotation is added on the subject of the myth of Orpheus and Eurydice in the margins of Martianus Capella-manuscript Leiden, BPL 88 , fol. I70v, written in an Irish hand which has been identified as $\mathrm{I}^{2}$, a hand belonging to someone from the close circle of John the Scot. ${ }^{37}$

Eyridice: id est profunda intentio. ipsa ars musica in suis profundissimis rationibus eyridice dicitur. Cuius quasi maritus orpheus dicitur hoc est OPIOC $\Phi O N O Y$ id est pulcra vox. qui maritus si aliqua neglegentia artis virtutem perdiderit. veluti in quendam infernum profundae disciplinae descendit. de qua iterum artis regulas iuxta quas musicae voces disponuntur reducit. sed dum voces corporeas et transitorias profundae artis intentioni comparat. fugit iterum in profunditatem dicipline ipsa intentio. quoniam in vocibus apperere non potest. ac per hoc tristis remanet orpheus vocem musicam sine ratione retinens.

Eurydice: this is profound (intellectual) effort. The art of music itself is said to be Eurydice, in its deepest principles. And as her husband Orpheus is mentioned, that is 'orios fonou' that is beautiful voice. And this husband had lost the virtue of this art through some kind of negligence, as if he descends into a certain hell of profound discipline. And out of this he brings back again the rules of the art, according to which musical voices are ordered. But when he compares corporeal and transient voices of the profound intellectual effort of his art, this intellectual effort itself flees again in the depth of discipline, for it cannot appear in (human) voices. And for that reason Orpheus remains sad, having a musical voice without reason.

Orpheus, the magical singer from ancient myth, is here interpreted with a silent reference to Fulgentius' Mythologies: he is the source for the etymology of 'orea phone', or 'optima vox'. ${ }^{8}$ In Fulgentius, Eurydice is explained with profunda diiudicatio (profound judgement), but profunda intentio is frequent, for example, in the oldest gloss tradition to Martianus Capella, which precedes that of John the Scot. The myth of Orpheus and Eurydice is here presented as an allegory of the difficult and perhaps even impossible path of learning: the beautiful voice (that is, the scholar with his eloquence and hard earned learning) strives to capture and keep profound understanding of the pure knowledge of the liberal arts. He even descends to Hell to recapture it after having lost it for the first time. But his strivings are in vain: he will never be able to fully understand, it is out of his reach. So the Fulgentian setting was 
taken as a starting point to go somewhere else, to a line of thinking and reasoning that is, in fact, very recognizable in other writings by John the Scot, but not part of the immediate context of the annotation. ${ }^{39}$

One wonders how the Carolingian scholars actually went about to accomplish their work in the margin: were they using the books they had in their library? Were they relying on their memory? Were they using intermediary collections, such as glossaries or compendia? Were they using intermediate materials, such as wax tablets or scraps of parchment to organize their material before starting to work? Probably all of the above, but how, then, can we trace their working methods? In order to answer these questions, more research is needed: too few texts of the above described kind have been edited with an eye for their intertextual relationships, and their connections to other texts that were part of the web of texts deployed for reading, understanding and studying the ancient learned tradition. It will be a challenge for the future to map the relations between marginal annotations and other genres of knowledge texts, such as glossaries, encyclopaedic collections and personal notebooks, and develop a more firm grip on the shared strategies for the management of knowledge in the early Middle Ages in the process.

\section{How to make editions of marginal texts? Some observations}

Let us now return to the core business of this group: how could we or should we make editions of marginal texts? I have tried to sketch the aspects of marginal text that make them interesting research material, but also difficult from the viewpoint of the editor. As Rita Copeland observed: 'a manuscript containing marginal commentary was a personal item, specific to the teaching and interests of its owner, and unlikely to be copied in exactly the same way'. ${ }^{\circ}$ This results in a fluidity, an essential quality of variance with which traditional philology is not comfortable. Another essential quality of marginal text seems to be that it attracts new text: new layers of marginal text entered by contemporary or later scribes, creating a process of text accumulation rather than a static single text.

I also talked about marginal features, which are not always textual in nature - the marginal symbols that bring structure and attach new meaning or interpretational levels to a text- pointing the reader in a certain direction, cautioning him or her, or even attacking the author. 
An editor will perhaps be inclined to dismiss these as 'not in his job description', since they are not always 'text'. Still, they may contain important information that reveal the voices talking back to the text.

Further, I talked about marginalia as nodes in intertextual webs of texts: they use other texts, cut them up, transform them in the process, deploy them in new settings, and embed texts in new contexts. What kinds of information would an edition ideally offer to get a grip on these phenomena?

First, in order to gain an understanding of the content and meaning of marginal texts, we need to know about their 'centre', so to speak: we need to know the content and gist of the main text to which they respond. I would therefore demand from every edition of a commentary tradition that it includes enough of the main text to get an idea, and plead for an edition in which larger portions of the main text are first presented, and then the individual lemmata to which annotations are attached are listed.

Second, to get an understanding of the fluidity of the texts, it would be necessary to have (if possible) multiple manuscripts in the comparison. Only when several exemplars of an annotated text are compared to each other it becomes possible to assess which part of the commentary tradition is more fixed, belongs to the 'core' of the tradition, so to speak, and which part is unique to a particular manuscript or set of manuscripts. Only then can we distinguish individual ad hoc annotations from set commentary traditions - by which I mean marginal text which is transmitted as a set text that adheres (to a certain degree) to the rules of standard text transmission: a certain striving for stability and consistency. But, as I have indicated earlier, in the case of marginal text this is always a matter of a certain scale of fluidity versus stability, a gliding scale between the two extremes.

To gain an understanding of the layers of marginal text, it would be necessary to apply some kind of genetic criticism, to encode the growth or development of a particular marginal unit, a marginal set of texts so that at some point, the user can see what was added when, and possibly also where. Where in traditional scholarship editors experimented with adding a $\mathrm{I}$ and 2 to correcting hands, to mark which one wrote first, and which one second, we could perhaps find new ways to visualize these layers of change to a text in a clearer way. In a digital edition, we could perhaps design a moving map of a certain manuscript, highlighting with colours which parts came first, which later, and which in a third stage of study or use of the text. We could make them layers 
on a white canvas, which can be shown to the user in the combination or order he or she chooses. If available, we could perhaps even relate those stages to certain dates or persons. However, I am well aware that the visualization of the layers of a certain marginal text is difficult to combine with my earlier point about the fluidity of texts: whereas the fluidity of texts can only be shown in relation to other copies of it, the layers are bound to be unique for each manuscript.

The encoding of the interconnectedness of marginal texts to other texts is, to my mind, the trickiest aspect. The standard way to encode this is to set up an apparatus of 'sources' in the widest sense of the word, ${ }^{4 \mathrm{I}}$ but a marginal text is in fact a set of texts, and each individual annotation would need its own apparatus, creating a rather confusing page when presented in the standard layout of a modern scholarly edition. ${ }^{42}$ But if we could visualize in some way how many and which other authorities marginal texts connect to the main texts, this would indeed improve our understanding of the basic set of texts available to our commentators. We could, for example, encode references to Isidore, Bede etcetera in different colours - yellow for Isidore, green for Bedeso that the elements from which the Carolingian scholar assembled his commentary will be visible as a coded wall built from colourful pieces.

I am well aware that the colour coding of each building block will be problematic: even if a piece of knowledge is retraceable to Bede, it will not necessarily have been taken from Bede, but can also come from intermediary sources. Yet it may advance our understanding of marginal text greatly if we stop seeing it as a set, solid text, and start seeing it as a web of texts, each annotation connected to other texts, forming nodes in the web. We may then, in the end, be able to see patterns: the preference of certain authorities in certain literary communities, the hierarchy of authorities on certain subjects, the deliberate spread of a certain text from a certain centre to other parts of the empire.

All these wishes and requirements for the edition of commentaries are, of course, entirely impractical. How on earth would we be able to build such an edition, and how many years would it take us to complete such a task? Still, I am convinced that marginal texts force us to think outside the box when it comes to making editions. The current paper format just does not suffice; we need more layers and better means to visualize structure and movement, in order to gain a better understanding of these marginal texts. I am challenging you to think about new strategies that could, perhaps, work, even if it is for only one facet of the complexities of marginal texts. 


\section{Appendix}

Martianus Capella, De nuptiis II.I 74-I 78, as in Leiden, UB, VLF 48, fol. I 7r: Diplomatic transcription (with abbreviations silently expanded) of text and annotations; the digital edition is freely accessible at http:// martianus.huygens.knaw.nl.

\I74\$Venit etiam quaedam decens 3 I

a pudicissima 32 puellarum quae praesul 33 domus. custosque cylleniae. Verum themis 34 aut

astrea 35 aut aerigonae 36 dicebatur. spicas in manu caelatumque 37 ex hebeneo pinacem 3839

argumentis talibus afferebat. $\$ 175$ Serat in medio 40 avis aegyptia quae ibis memoratur

ab incolis. $\$$ I 76 \sed cum petaso 4I vertex atque os pulcherrimum videbatur. quod quidem serpen-

tis gemini lambebat implexio 42. subter quaedam praenitens 43 virga cuius caput auratum 44

media 45 glauca 46 . piceus 47 finis extabat. sed dextro 48 textudo minitansque 49 nepa 50 a

leva 5 I caprea. $\ I 77 \$$ sedilofon alitem quae sit oscinum mitior 52 in certaminis temptamenta 53

pulsabat 54 . $\$$ I 78 Ipsa vero ibis praenotatum 55 gerit 56 nomen mensis 57 cuiusdam memphytici.

\section{I DECENS honesta}

32 PUDICISSIMA castissima

33 PRAESUL deus qui inferorum potestatem et superiorum habet quasi ostiarius

34 THEMIS obscuritas

35 ASTREA stellata

36 AERIGONAE virgo

37 CAELATUMQUE scultam

38 PINACEM tabulam

39 EX HEBENEO PINACEM haec tabula sub figura artis negotiatoriae describitur. Mercurius itaque quasi mercatorum chirrius id est dominus. Erigone autem custos domus Cilleniae ipsam artem negotiatoria signat quae habet formam et imaginem petasi quia omnis negotiator velocissime omnes terras et regiones amore pecuniae motu quasi quoddam volatile lustrat. Habet serpentes quia institorum lingua venenosa est ad fallent habet virgam quasi ipsam artem quae primo introitu quasi pulcherrima 
videtur in processu vero vilescit quod significatur per glaucum colorem in fine ad mortem ducit. Per capream velocitas mercatorum significatur 40 IN MEDIO pinnacis

4 I PETASO talaribus sumitas illius tabulae

42 LAMBEBAT implexio attingebat circumdatio

43 PRAENITENS pinnacem

44 AURATUM erat

45 MEDIA in medio

46 GLAUCA id est viridis

47 PICEUS nigerrimus

48 SED DEXTRO pinnacis indumento

49 MINITANSQUE illa virgo

50 NEPA nepa a nepais declinatur

5 I LEVA ubi iste dicit quod a leva fuisset caprea dilofon dicit quod fuisset ales cum serpentibus

52 OSCINUM MITIOR quasi mitissima omnium avium ore canentium

53 TEMPTAMENTA per inpedimenta

54 PULSABAT percutiebat

55 PRAENOTATUM praescriptum

56 GERIT portat

57 NOMEN MENSIS gerpeios et signum et mensis vocatur apud Aegiptios mensis November et signum scorpios

\section{Notes}

I. This is a five-year VIDI project, sponsored by the Netherlands Organisation of Scientific Research (NWO) and housed at the Huygens Institute for the History of the Netherlands, Royal Netherlands Academy of Arts and Sciences. It runs from May 20I I to April 20I6, and it involves, besides myself as principal investigator, Irene van Renswoude (PostDoc researcher) and Evina Steinova $(\mathrm{PhD}$ researcher). See https://www.huygens.knaw.nl/marginal-scholarshipvidi/.

2. Other contributions in this series make the same point for different textual genres, e.g. E. Jeffreys, 'Tapestries of Quotation: The Challenges of Editing Byzantine Texts', and D. d'Avray, 'Contamination, Stemmatics and the Editing of Medieval Latin Texts', Ars Edendi Lecture Series, ed. by A. Bucossi and E. Kihlman, Vol. II (Stockholm: Stockholm University Press, 20I2), pp. 35-6I and 63-82. J.E.G. Zetzel makes the point for commentary texts: Marginal Scholarship and Textual Deviance: The 'Commentum Cornuti' and the Early Scholia on Persius, Bulletin of the Institute of Classical Studies Supplement 84 (London: Institute of Classical Studies, 2005), esp. Chapter 7, pp. I44-I6I. 
3. K. McNamee, Annotations in Greek and Latin texts from Egypt, American Studies in Papyrology 45 (Oakville, Conn.: American Society of Papyrologists, 2007).

4. This information was given to me by David Ganz, who shared with me a list of annotated manuscripts in CLA and his observations on them; I am very grateful for his generosity.

5. L. Holtz, 'Le rôle des commentaires d'auteurs classiques dans l'émergence d'une mise en page associant texte et commentaire (Moyen Âge occidental)', in Le commentaire entre tradition et innovation, ed. by Tiziano Dorandi and Marie-Odile Goulet-Cazé (Paris: Vrin, 2000), pp. IOI-I I7; R. Copeland, 'Gloss and Commentary', in The Oxford Handbook of Medieval Latin Literature, ed. by Ralph Hexter and David Townsend (Oxford: Oxford University Press, 20I2), pp. I7I-I9I.

6. Note that at least in Carolingian times, the relationship between the two forms is fluid: one can spill over into the other. Lemmatic commentary could be inserted in the margins, and marginal material could be stored in new, separate collections. Zetzel, Marginal Scholarship, esp. Chapter 5, pp. 86-I 26.

7. J.J. Contreni, 'The Carolingian Renaissance: Education and Literary Culture', and D. Ganz, 'Book Production in the Carolingian Empire and the Spread of Caroline Minuscule', in The New Cambridge Medieval History Vol. II: c. $700-c .900$, The New Cambridge Medieval History, II: c.700-c.900, ed. by Rosamond McKitterick (Cambridge: Cambridge University Press, 2015), pp. 709-757 and 786-808.

8. Holtz, 'Le rôle des commentaires', pp. I I I-I I 6.

9. Ganz, 'Book Production', 789-805; R. McKitterick, 'Glossaries and Other Innovations in Carolingian Book Production', in Turning Over a New Leaf: Change and Development in the Medieval Book, ed. by E. Kwakkel et al. (Leiden: Leiden University Press, 20I2), pp. 2I-76 (esp. pp. 2I-3 I).

IO. Evina Steinová researched a set of about I50 manuscripts primarily from Freising and Regensburg which were produced from the second half of the eighth century to the late ninth century. A very high percentage of them contained some form of annotation.

I I. Paris, BnF, Lat. I, available on the Gallica-website of the Bibliothèque Nationale de France: http:/gallica.bnf.fr/ark:/I2I48/btvib8455903b [last consulted November 20I4].

I 2. At this point (November 20I4), the database contains about 350 files with descriptions of ninth- and tenth-century codicological units. The database is freely accessible online: http://marginalia.huygens.knaw.nl/view/codices [last consulted 28 Nov. 20I 4], but is emphatically a work in progress. It still contains 
many inconsistencies and errors. The data that we collected in the database so far are: a good sample of Carolingian manuscripts from the Leiden University Library collection, manuscripts made in eighth-century Lorsch (accessible via the Bibliotheca Laureshamensis website), a sample of manuscripts from ninthcentury Corbie [described in D. Ganz, Corbie in the Carolingian Renaissance (Sigmaringen: Thorbecke Verlag, I990), and accessible (partly) via the Gallica website] and a large sample of manuscripts from the Bavarian region (accessible, mostly, via the website of the Bayerische Staatsbibliothek in München). We wish to collect more observations on manuscripts from Reims, Auxerre and Fleury, and on manuscripts which are connected to certain scholars, such as Lupus of Ferrières, Heiric of Auxerres and John Scottus Eriugena.

I3. C. Baswell, 'Talking Back to the Text: Marginal Voices in Medieval Secular Literature', in The Uses of Manuscripts in Literary Studies. Essays in Memory of Judson Boyce Allen, ed. by Charlotte C. Morse, Penelope R. Doob and Marjorie C. Woods, Studies in Medieval Culture 3I (Michigan: Michigan University Press, I992), pp. I2 I-I60 (p. I2I).

I4. Gernot Wieland showed a very convincing case of a book glossed for the purpose of treatment in the classroom: The Latin Glosses on Arator and Prudentius in Cambridge University Library Ms. Gg. 5. 35, Studies and Texts 6I (Toronto: Pontifical Institute of Mediaeval Studies, I983), but in the wake of his study every annotated book tended to be interpreted in the same manner. A good attempt to give the schoolbook model more complexity and depth is found in A. Tura, 'Essai sur les marginalia en tant que pratique et documents', in Scientia in margine. Études sur les marginalia dans les manuscrits scientifiques du Moyen Âge à la Renaissance, ed. by Danielle Jacquart and Charles Burnett (Genève: Droz, 2005), pp. 26I-387.

I 5. On Martianus, see W.H. Stahl and R. Johnson, Martianus Capella and the Seven Liberal Arts, 2 vols (New York: Columbia University Press, I97I, repr. I977); S. Grebe, Martianus Capella 'De nuptiis Philologiae et Mercurii'. Darstellungen der sieben Freien Künste und ibrer Beziehungen zueinander, Beiträge zur Altertumskunde I I 9 (Stuttgart, Leipzig: Teubner, I999); I. Ramelli, Marziano Capella, Le nozze di Filologia e Mercurio (Milan: Bompiani, 200I).

I6. Ed. J. Willis, Martianus Capella (Leipzig: Teubner, I983), pp. 50-5I; transl. Stahl \& Johnson, Martianus Capella, Vol. 2, pp. 56-57.

I7. I owe this example to a paper given by Padraíc Moran at the International Medieval Congress at Kalamazoo in May 2009.

I 8. The digital edition is online at http://martianus.huygens.knaw.nl/path [last consulted 28 Nov. 20I4]; for a critical edition of the annotations to books I and II of De nuptiis comparing twenty manuscripts, we now also have Sinéad O'Sullivan's edition: Glossae Aevi Carolini in libros I-II Martiani Capellae 
de nuptiis Philologiae et Mercurii, Corpus Christianorum Continuatio Mediaevalis 237 (Turnhout: Brepols, 2010).

I9. O’Sullivan, Glossae Carolini Aevi, pp. 396-400.

20. M. Teeuwen, Harmony and the Music of the Spheres. The Ars Musica in Ninth-Century Commentaries on Martianus Capella, Mittellateinische Studien und Texte 30 (Leiden, Boston, Köln: Brill, 2002), pp. I 62-I 83 .

2. F. Cinato, 'Les gloses carolingiennes à l'Ars Prisciani: méthode d'analyse', in Priscien. Transmission et refondation de la grammaire de l'Antiquité aux Modernes, ed. by Marc Baratin, Bernard Colombat, and Louis Holtz, Studia Artistarum 2I (Turnhout: Brepols, 2009), pp. 429-444.

22. S. Ottaviano, 'Il Reg. Lat. I669: un'edizione di Virgilio d'età carolingia', Miscellanea Bibliothecae Apostolicae Vaticanae, I6 (2009), 259-324 (esp. pp. 266-267; 293-296); S. Ottaviano, 'Scholia non Serviana nei manoscritti carolingi di Virgilio: prime notizie degli scavi', Exemplaria Classica, I7 (2013), 223-246 (esp. pp. 237-242).

23. Even though Ann Blair's book, Too Much to Know: Managing Scholarly Information before the Modern Age (New Haven, London: Yale University Press, 2010), focuses on a different period of history, her general ideas about information management are very apt here.

24. Evina Steinová, Notam superponere studui: The Use of Technical Signs in the Early Middle Ages, available online via the portal Narcis: http://www. narcis.nl/search/Language/NL/coll/publication/uquery/. For a first sketch, see Evina Steinová, 'Psalmos, notas, cantus: the Meanings of Nota in the Carolingian Period', Speculum, 90:2 (201 5), 424-457.

25. Example taken from Evina Steinová's work: Münich, Bayerische Staatsbibliothek, Clm 343, p. 6.

26. This example is treated in I. van Renswoude and E. Steinová, 'The Annotated Gottschalk: Symbolic Annotation and Control of Heterodoxy in the Carolingian Age', in La controverse carolingienne sur la prédestination. Histoire, texte, manuscrits, ed. by P. Chambert-Protat, J. Delmulle, W. Pezé and J. C. Thompson, Collection des Études Augustiniennes (Paris, forthcoming).

27. This case has been studied by Hanssens, Wilmart, Zechiel Eckes and Van Renswoude: J.-M.Hanssens, ed., Amalarii episcopi opera liturgica omnia, Vol. 2, Liber officialis (Città del Vaticano: Biblioteca Apostolica Vaticana, I949); A. Wilmart, 'Un lecteur ennemi d'Amalaire', Revue Bénédictine, 36 (I924), 3 I7-329; K. Zechiel-Eckes, Florus von Lyon als Kirchenpolitiker und Publizist. Studien zur Persönlichkeit eines karolingischen "Intellektuellen" am Beispiel der Auseinandersetzung mit Amalarius (835-838) und des Prädestinationsstreits (85I-855), Quellen und Forschungen zum Recht im Mittelalter, 8 
(Stuttgart: Thorbecke Verlag, I999), pp. 72-76; I. van Renswoude, 'The Art of Disputation: Dialogue, Dialectic and Debate in Late Antiquity and the Early Medieval West', forthcoming in a special issue of Early Medieval Europe: Cultures of Dialogue and Debate in Late Antiquity and the Early Medieval West, ed. by M. B. de Jong and I. van Renswoude (winter issue 20I6). A digital facsimile of the manuscript is online available on the Gallica website: http:// gallica.bnf.fr/ark:/I2I48/btvibio3 I 5686 s [last visited 28 Nov. 20I4].

28. C. Charlier, 'Les manuscrits personnels de Florus de Lyon et son activité littéraire', in Mélanges E. Podechard. Études de sciences religieuses offertes pour son éméritat (Lyon: Facultés Catholiques, I945), pp. 7 I-84; repr. in Revue Bénédictine, I 19 (2009), 252-267; L. Holtz, 'Le ms. Lyon, B.M. 484 (4I4) et la méthode de travail de Florus', Revue Bénédictine, I 19 (2009), 270-3 I 5.

29. Amalarius, Liber officialis, II.5.5: "Superiorem partem capitis rasorio saepe renovamus, cum forti sollicitudine superfluas temporariasque cogitationes de superiore parte animi resecamus.”: ed. Hanssens, Vol. II, p. 2I I, 11. 23-25.

30. Paris, BnF, NAL 329, fol. 82r; ed. Hanssens, Vol. II, p. 573.

3 I. Baswell, 'Talking Back to the Text', p. I22.

32. Ibid., p. I35.

33. Renswoude and Steinová, 'The Annotated Gottschalk'.

34. There is also an annotated copy of the Libri Carolini, to wit Vatican City, BAV, Vat. lat. 7207. It has been suggested that this annotated copy was deliberately secured to prevent further transmission in the Vatican archives. See A. Freeman and P. Meyvaert, 'Further Studies in the "Libri carolini" III: the Marginal Notes in "Vaticanus latinus" 7207', in Theodulf of Orleans: Charlemagne's Spokesman against the Second Council of Nicaea, ed. by Ann Freeman and Paul Meyvaert (Aldershot: Variorum, 2003), pp. 597-6I2; I. van Renswoude and M. Teeuwen, 'Voorpublicatie, censuur en zelfcensuur in Oudheid en Middeleeuwen. Hoe een auteur zich kan wapenen tegen openbare kritiek en straf', in in In vriendschap en vertrouwen. Cultuurbistorische essays over confidentialiteit, ed. by Jos Gabriëls, Ineke Huysman et al. (Hilversum: Verloren, 20I4), pp. $24 \mathrm{I}-256$ (p. 249).

35. Teeuwen, Harmony, pp. I 62-I 83; M. Teeuwen, 'Writing between the Lines: Reflections of Scholarly Debate in a Carolingian Commentary Tradition', in Carolingian Scholarship and Martianus Capella: Ninth-Century Commentary Traditions on 'De nuptiis' in Context, ed. by M. Teeuwen and S. O'Sullivan, CELAMA I2 (Turnhout: Brepols, 20II), pp. I I-34 (pp. 28-3I).

36. The metaphor was suggested by M. Garrison, 'Questions and Observations Based on Transcribing the Commentary on Books IV and V, Dialectic and Rhetoric', in Marginal Scholarship and Martianus Capella, ed. by Teeuwen 
and O'Sullivan, pp. I53-I74 (p. I74): “These preliminary soundings of the glosses to Books IV and V have not found a large role for either systematically arranged handbooks ... nor for alphabetical compendia.... Rather, wide reading, sometimes imperfectly recalled, and perhaps expounded in discussion, seems to underlie the glosses.... And thus, though the topics chosen, and even the manner of elucidation, may sometimes seem whimsical rather than systematic, far from deserving comparison to intellectual fly-paper or a magpie's stash, the glosses were a truly precious repository of hard-won learning, worth saving even when later proven incorrect.”

37. The page is available in the digital photograph collection of Leiden University Library: go to https://socrates.leidenuniv.nl/, and search for BPL 88 [last consulted in Nov. 20I4]. For a thorough analysis of $\mathrm{I}^{\mathrm{I}}$ and $\mathrm{I}^{2}$, see É. Jeauneau and P.E. Dutton, The Autograph of Eriugena, Corpus Christianorum Autographa Medii Aevi 3 (Turnhout: Brepols, I996).

38. Fulgentius Mythographus, Mythologiarum libri tres, 3.Io, ed. R. Helm [Leipzig I 898], 77.

39. See also S. Boynton, 'Sources and Significance of the Orpheus Myth', Early Music History, I 8 ( I999), 47-74.

40. Copeland, 'Gloss and Commentary', p. I74.

4I. That is: including references to works which are not direct sources, but rather parallels in an indirect way, for example via a shared intermediary source.

42. This method was chosen by M. Bernhard and C.M. Bower, for their edition of the Glossa maior in institutionem musicam Boethii, 4 vols, Bayerische Akademie der Wissenschaften, Veröffentlichungen der Musichistorischen Kommission Band 9-I2 (München: Verlag der Bayerischen Akademie der Wissenschaften, I993, I994, I996, 20II). To my mind, it works rather well here, but a more complex commentary tradition will be difficult to capture.

\section{Bibliography}

Baswell, C., 'Talking Back to the Text: Marginal Voices in Medieval Secular Literature', in The Uses of Manuscripts in Literary Studies. Essays in Memory of Judson Boyce Allen, ed. by Charlotte C. Morse, Penelope R. Doob and Marjorie C. Woods, Studies in Medieval Culture 3 I (Michigan: Michigan University Press, I992), pp. I2 I-I60

Bernhard, Mikael and Bower, C.M., eds, Glossa maior in institutionem musicam Boethii, 4 vols, Bayerische Akademie der Wissenschaften, Veröffentlichungen der Musichistorischen Kommission Band 9-I2 (München: Verlag der Bayerischen Akademie der Wissenschaften, I993, I994, I996, 20I I) 
Blair, Ann, Too Much to Know: Managing Scholarly Information before the Modern Age (New Haven, London: Yale University Press, 2010)

Boynton, Susan, 'Sources and Significance of the Orpheus Myth', Early Music History, I 8 (1999), 47-74

Charlier, Célestin, 'Les manuscrits personnels de Florus de Lyon et son activité littéraire', in Mélanges E. Podechard. Études de sciences religieuses offertes pour son éméritat (Lyon: Facultés Catholiques, I945), pp. 7I-84; repr. in Revue Bénédictine, I I9 (2009), 252-267

Cinato, Franc, 'Les gloses carolingiennes à l'Ars Prisciani: méthode d'analyse', in Priscien. Transmission et refondation de la grammaire de l'Antiquité aux Modernes, ed. by Marc Baratin, Bernard Colombat, and Louis Holtz, Studia Artistarum 2I (Turnhout: Brepols, 2009), pp. 429-444

Contreni, John J., 'The Carolingian Renaissance: Education and Literary Culture', in The New Cambridge Medieval History, II: c.700-c.900, ed. by Rosamond McKitterick (Cambridge: Cambridge University Press, 2015), pp. 709-757

Copeland, Rita, 'Gloss and Commentary', in The Oxford Handbook of Medieval Latin Literature, ed. by Ralph Hexter and David Townsend (Oxford: Oxford University Press, 20I2), pp. I7I-I9I

d'Avray, David, 'Contamination, Stemmatics and the Editing of Medieval Latin Texts', in Ars Edendi Lecture Series, ed. by A. Bucossi and E. Kihlman, Vol. II (Stockholm: Stockholm University Press, 20I 2), pp. 63-82

Freeman, Ann and Meyvaert, Paul, 'Further Studies in the "Libri carolini" III: the Marginal Notes in "Vaticanus latinus" 7207', in Theodulf of Orleans: Charlemagne's Spokesman against the Second Council of Nicaea, ed. by Ann Freeman and Paul Meyvaert (Aldershot: Variorum, 2003), pp. 597-6I 2

Ganz, David, 'Book Production in the Carolingian Empire and the Spread of Caroline Minuscule', in The New Cambridge Medieval History Vol. II: c. 700-c. 900, The New Cambridge Medieval History, II: c.700-c.900, ed. by Rosamond McKitterick (Cambridge: Cambridge University Press, 2015), pp. $786-808$

Ganz, David, Corbie in the Carolingian Renaissance (Sigmaringen: Thorbecke Verlag, I990)

Garrison, Mary, 'Questions and Observations Based on Transcribing the Commentary on Books IV and V, Dialectic and Rhetoric', in Carolingian Scholarship and Martianus Capella: Ninth-Century Commentary Traditions on 'De nuptiis' in Context, ed. by Mariken Teeuwen and Sinéad O'Sullivan, CELAMA I 2 (Turnhout: Brepols, 20I I), pp. I47-I 76 
Grebe, Sabine, Martianus Capella 'De nuptiis Philologiae et Mercurii'. Darstellungen der sieben Freien Künste und ihrer Beziehungen zueinander, Beiträge zur Altertumskunde I I9 (Stuttgart, Leipzig: Teubner, I999)

Hanssens, Jean-Michel, André Wilmart, Klaus Zechiel-Eckes, and Irene Van Renswoude, eds, Amalarii episcopi opera liturgica omnia, Vol. 2, Liber officialis (Città del Vaticano: Biblioteca Apostolica Vaticana, I949)

Helm, Rudolf, ed., Fulgentius Mythographus, Mythologiarum libri tres, 3.Io [Leipzig I 898]

Holtz, Louis, 'Le ms. Lyon, B.M. 484 (4I4) et la méthode de travail de Florus', Revue Bénédictine, I I9 (2009), 270-3 I 5

Holtz, Louis, 'Le rôle des commentaires d'auteurs classiques dans l'émergence d'une mise en page associant texte et commentaire (Moyen Âge occidental)', in Le commentaire entre tradition et innovation, ed. by Tiziano Dorandi and Marie-Odile Goulet-Cazé (Paris: Vrin, 2000), pp. IOI-I I7

Jeauneau, Éduard, and Paul Edward Dutton, The Autograph of Eriugena, Corpus Christianorum Autographa Medii Aevi 3 (Turnhout: Brepols, I996)

Jeffreys, Elisabeth M., 'Tapestries of Quotation: the Challenges of Editing Byzantine Texts', in Ars Edendi Lecture Series, Vol. II, ed. by Alessandra Bucossi and Erika Kihlman (Stockholm: Stockholm University Press, 20I2), pp. 35-6I

McKitterick, Rosamond, 'Glossaries and Other Innovations in Carolingian Book Production', in Turning Over a New Leaf: Change and Development in the Medieval Book, ed. by E. Kwakkel et al. (Leiden: Leiden University Press, 20I 2), pp. 2I-76

McNamee, Kathleen, Annotations in Greek and Latin Texts from Egypt, American Studies in Papyrology 45 (Oakville, Conn.: American Society of Papyrologists, 2007)

O’Sullivan, Sinéad, ed., Glossae Aevi Carolini in libros I-II Martiani Capellae de nuptiis Philologiae et Mercurii, Corpus Christianorum Continuatio Mediaevalis 237 (Turnhout: Brepols, 2010)

Ottaviano, Silvia, 'Scholia non Serviana nei manoscritti carolingi di Virgilio: prime notizie degli scavi', Exemplaria Classica, I7 (2013), 223-246

Ottaviano, Silvia, 'Il Reg. Lat. I669: un'edizione di Virgilio d'età carolingia', Miscellanea Bibliothecae Apostolicae Vaticanae, I6 (2009), 259-324

Ramelli, Ilaria, Marziano Capella, Le nozze di Filologia e Mercurio (Milan: Bompiani, 200I)

Renswoude, Irene van, and Evina Steinová, 'The Annotated Gottschalk: 
Symbolic Annotation and Control of Heterodoxy in the Carolingian Age', Collection des Études Augustiniennes (forthcoming)

Renswoude, Irene van, and Mariken Teeuwen, 'Voorpublicatie, censuur en zelfcensuur in Oudheid en Middeleeuwen. Hoe een auteur zich kan wapenen tegen openbare kritiek en straf', in In vriendschap en vertrouwen. Cultuurhistorische essays over confidentialiteit, ed. by Jos Gabriëls, Ineke Huysman et al. (Hilversum: Verloren, 20I4), pp. 24 I-256

Renswoude, Irene van, 'Dissent, Dialectic and Control of Christian Discourse in the Carolingian Period', paper for the International conference Ethnicity and Christian Discourse in the Early Middle Ages, Vienna I 8-I9 June 20 I 2 (forthcoming)

Stahl, William Harris, and Richard Johnson, Martianus Capella and the Seven Liberal Arts, Vol. I-2 (New York: Columbia University Press, I97I, repr. I977)

Steinová, Evina, Notam superponere studui: The Use of Technical Signs in the Early Middle Ages, doctoral dissertation, University of Utrecht, 2016

Steinová, Evina, 'Psalmos, notas, cantus: the Meanings of Nota in the Carolingian Period', Speculum, 90:2 (201 5), 424-457

Teeuwen, Mariken, 'Writing between the Lines: Reflections of Scholarly Debate in a Carolingian Commentary Tradition', in Carolingian Scholarship and Martianus Capella: Ninth-Century Commentary Traditions on 'De nuptiis' in Context, ed. by Mariken Teeuwen and Sinéad O'Sullivan, CELAMA I 2 (Turnhout: Brepols, 20I I), I I-34

Teeuwen, Mariken, Harmony and the Music of the Spheres. The Ars Musica in Ninth-Century Commentaries on Martianus Capella, Mittellateinische Studien und Texte 30 (Leiden, Boston, Köln: Brill, 2002)

Tura, Adolfo, 'Essai sur les marginalia en tant que pratique et documents', in Scientia in margine. Études sur les marginalia dans les manuscrits scientifiques du Moyen Âge à la Renaissance, ed. by Danielle Jacquart and Charles Burnett (Genève: Droz, 2005), pp. 26I-387

Wieland, Gernot, The Latin Glosses on Arator and Prudentius in Cambridge University Library Ms. Gg. 5. 35, Studies and Texts 6I (Toronto: Pontifical Institute of Mediaeval Studies, I983)

Willis, James, ed., Martianus Capella (Leipzig: Teubner, I983)

Wilmart, André, 'Un lecteur ennemi d'Amalaire', Revue Bénédictine, 36 (I924), 317-329

Zechiel-Eckes, Klaus, Florus von Lyon als Kirchenpolitiker und Publizist. Studien zur Persönlichkeit eines karolingischen "Intellektuellen" am 
Beispiel der Auseinandersetzung mit Amalarius (835-838) und des Prädestinationsstreits (85I-855), Quellen und Forschungen zum Recht im Mittelalter 8 (Stuttgart: Thorbecke Verlag, 1999)

Zetzel, James E.G., Marginal Scholarship and Textual Deviance: the 'Commentum Cornuti' and the Early Scholia on Persius, Bulletin of the Institute of Classical Studies Supplement 84 (London: Institute of Classical Studies, 2005)

\section{Manuscripts}

Münich, Bayerische Staatsbibliothek, Clm 343

Paris, BnF, Paris. lat. I, available on the Gallica-website of the Bibliothèque Nationale de France: http://gallica.bnf.fr/ark:/I 2I 48/btvib8455903b http://marginalia.huygens.knaw.nl/view/codices http://gallica.bnf.fr/ark:/I 2 I 48/btvibio3 I $5686 \mathrm{~s}$ Paris, BnF, NAL 329

Vatican City, BAV, Vat. lat. 7207 